Научна критика

УДК 811.163.41:801.6(049.32)

$811.163 .41^{\prime} 342.1(049.32)$

811.163.41'342.8(049.32)

Примљен: 31. марта 2021.

Прихваћен: 1. априла 2021.

https://doi.org/10.46630/phm.13.2021.72

\title{
СРПСКИ ЈЕЗИК У СВЕТЛУ САВРЕМЕНИХ АКУСТИЧКИХ ИСТРАЖИВАҢА
}

(Александра Лончар Раичевић, Акустичка анализа прозодије речи $у$ српском језику, Филозофски факултет, Ниш, 2020)

Прва фонетска истраживања заснована на методама акустичке анализе говорног сигнала везују се за период почетка XX века, када су разноврсна технолошка открића условила развој ове гране фонетике. У науци у српском језику први радови у којима је извршена темељна акустичка анализа вокала, настали су шездесетих година прошлог века, а везују се за рад Павла Ивића и Илсе Лехисте. Отада се јавило неколико имена у науци која су свој рад у области фонетике формирала у правцу примене нових експерименталних метода, међу којима је и професор Филозофског факултета у Нишу, Александра Лончар Раичевић. Свим досадашњим радовима и монографијама аутор је пружио изузетан допринос фонетици и фонологији, пре свега акустичким описима акцената у српском језику, а подаци најновијих експерименталних истраживања сублимирани су у монографији која је недавно објављена.

Крајем 2020. године, у издању Филозофског факултета Универзитета у Нишу, објављена је књига Акустичка анализа прозодије речи у српском језику проф. др Александре Лончар Раичевић. Аутор је из угла акустичке анализе говора, а на основу спроведених истраживања у којима су учествовали изворни говорници, дао акустички опис прозодијских јединица у савременом српском језику. Књига је намењена лингвистима, фонетичарима, форензичарима, као и студентима језика којима ће она бити вишеструко корисна.

Књига Акустичка анализа прозодије речи у српском језику има 215 страна и обухвата следећих 16 поглавља: Увод (стр. 9-13), Методологија (стр. 13-19), Најстарији описи српског акценатског система (стр. 19-23), Фонетска природа акцената (стр. 23-38), Прозодијски систем стандардног српског језика (стр. 38-41), Акиенатске особине говора Златибора (стр. 41-63), Акустичке особине прозодије речи (стр. 63-70), Трајане вокала, прва група (стр. 70-92), Фреквениија основног тона (стр. 
92-115), Интензитет (стр. 115-121), Трајане вокала, друга група (стр. 12-131), Фреквенција основног тона (стр. 132-148), Интензитет (стр. 148-152), Неакцентоване дужине (стр. 152-171), Дискусија и заклучак (стр. 171-181), Социобонетски аспект проучаваға говора (стр. 181-193). Након последњег поглавља следе Корпус за експерименталну анализу (стр. 193-197), Скраћенице (стр. 197-198) и Литература (стр. 198-215). Сама структура монографије, као и називи поглавља, сведоче да се дуго и темељно радило на публикацији рукописа и да су њиме обухваћени сви битни моменти прозодије српског језика: од најстаријих описа акценатског система до резултата актуелних истраживања.

На самом почетку, у поглављу које носи наслов Увод, аутор истиче да је књига настала на темељима докторске дисертације под називом Прозодија речи у говорима ужичког краја, употпуњена новим истраживањима и социофонетским погледима у проучавањима говора: такође, истакнуто је да је на избор истраживачког проблема утицала чињеница да истраживања новоштокавских говора имају за циљ прикупљање података који су неопходни за ревизију постојеће акценатске норме.

Аутор је у књизи одговорио на све циљеве који су представљени на почетку књиге у одељку Увод (стр. 9-13): први циљ јесте употпуњавање дијалекатских спознаја о прозодијским особинама речи говора становника наведене области; други циљ - прецизан фонетски опис природе акцената кроз анализу параметара трајања, фреквенције основног тона (f0) и интензитета у наглашеним и ненаглашеним постакценатским слоговима; трећи циљ је анализа социофонетског аспекта продукције говора. Сва три циља су у потпуности остварена, с обзиром на то су истраживања вршена у говору изворних испитаника из Ужица, те су тиме дијалекатска сазнања о овом ареалу проширена и употпуњена; главни део књиге јесу резултати експерименталне анализе материјала, а обухваћени су они акустички параметри које је аутор навео, а који су неопходни да би се акценатске јединице у језику објективно и прецизно описале; последње поглавље доноси поглед на социофонетску литературу и могућа проучавања говора из овог угла.

У поглављу Методологија (стр. 13-19) представљене су методе рада и технике истраживања које се базирају на експерименталној методи: акустичка анализа у софтверском пакету за обраду говора $P R A A T$ (верзија 6.1.15, Boersma-Weenick 2020). Такође, изложени су подаци у вези са испитаницима и корпусом, чија анализа представља срж и централни део спроведеног истраживања - подаци у вези са корпусом налазе се и у одељку Корпус за експерименталну анализу (стр. 193-197), на крају књиге. Коришћени примери предствљени су кроз табеле, према вокалској јединици и нормативно очекиваној акценатској категорији. 
Квантитативна (статистичка) анализа добијених вредности доприноси објективном и прецизном сагледавању података, који су у централном делу књиге представљени табеларно.

У трећем и четвртом поглављу - Најстарији описи српског акценатског система (стр. 19-23) и Фонетска природа акцената (стр. 23-38) - приказана су досадашња проучавања акценатског система српског језика од најстаријих, која су се базирала на перцептивним методама, до најновијих - експерименталних. Наведена поглавља вишеструко су корисна јер пружају увид у историјски и хронолошки развој проучавања акценатског система српског језика, од Луке Милованова (средина XIX) до данас. На овај начин сви они који се баве овом проблематиком могу на једном месту пронаћи имена аутора и њихових дела, као и значајне резултате који су обележили њихов рад.

Основне информације о прозодијском систему стандардног српског језика, али и о ужичком варијетету, дате су у поглављу петом и шестом поглављу - Прозодијски систем стандардног српског језика (стр. 38-41) и Акценатске особине говора Златибора (стр. 41-63). Наведена поглавља су од изузетног значаја јер се у њима, поред основних информација о прозодијском систему савременог српског језика, разматрају и сагледавају и спорна ортоепска питања, као што су статус неакцентованих дужина, акцентуација речи страног порекла и акцентуација генитива множине. Аутор књиге истиче да се као последица дијалекатских промена у језичкој бази и измењених друштвених прилика јавља нагли продор стране лексике, као и извесне промене у прозодијском систему српског језика. Овакве промене представљају битан и озбиљан проблем коме треба приступити постепено, преиспитујући досадашња правила и формирајући нова у складу са свим забележеним иновацијама у језику и у друштву.

Наредних седам поглавља представљају кључни део књиге Акустичка анализа прозодије речи у српском језику јер су у њима представљена сва сазнања о акустичком аспекту проучавања говора. У седмом одељку - Акустичке особине прозодије речи (стр. 63-70), теоријски су описани сви они акустички параметри који су анализирани у централном делу књиге, а дати су и основни прикази звука - спектрограм и осцилограм. Од осмог до четрнаестог поглавља детаљно су анализирани акустички параметри трајања, фреквенције основног тона и интензитета говорног сегмента. Чињеница да су резултати представљени у продукцији говорника двеју узрасних група - деца (8-10 година) и млађа група (18-20 година), указује на социофонетску оријентацију истраживања.

Трајање вокала у продукцији испитаника сагледано је у односу на неколико битних фонетских контекста: врста слога (наглашен и не- 
наглашен), број слогова, супрасегментална обележја (нормативно очекивана акценатска категорија), консонантско окружење - звучно/безвучно. Такође, проучавано је трајање вокала у ненаглашеним, постакценатским слоговима у односу на врсту акценатске јединице у акцентованом слогу, као и у односу на постакценатску дужину, односно краткоћу. На крају ових поглавља сагледано је трајање вокала у односу на фонолошку позицију - дуг/кратак акцентовани вокал, дуг/кратак неакцентовани вокал. Аутор износи вредности до којих је дошао анализом материјала и пореди сопствене резултате са подацима датим у релевантној литератури. Лончар Раичевић закључује да се код говорника у чијој основи лежи ужички урбани варијетет примећује систематска разлика трајања појединих вокала. Вокали под дугосилазним акцентом имају дуже трајање од вокала под дугоузлазним акцентом, осим код вокала [о], док вокали под краткоузлазним акцентом дуже трају од вокала под краткосилазним акцентом. Резултати истраживања показују да тенденцију дужег трајања имају вокали у звучном него у безвучном сугласничком окружењу. Аутор закључује, на основу анализе прикупљеног и обрађеног материјала, да трајање вокала под акцентом, као и трајање неакцентоване дужине и краткоће, у мањој мери зависе од инхерентног трајања самог вокала, а знатно више од врсте акценатске јединице, природе сугласника и броја слогова унутар посматране речи.

Фреквенција основног тона приказана је у деветом (стр. 92-115) и дванаестом поглављу (стр. 132-148), опширно и систематично. Поглавља садрже детаљне табеларне приказе фреквенције основног тона и сликовне приказе интонацијских контура. Како овај параметар у српском језику истовремено треба да оствари две функције - истакнутост слога и фонолошку разликовну функцију акцента, једино се његовом анализом прецизно могу успоставити дистинкције између узлазних и силазних акцената. Лончар Раичевић овај параметар сагледава код двосложних и тросложних речи, а прати кретање тона у наглашеном вокалу, кретање тона у ненаглашеном вокалу и укупан пад тонске линије од врхунца акцентованог слога до краја следећег слога. У овим поглављима приказани су интонацијски облици у двосложним и тросложним речима под нормативно очекиваним краткосилазним, краткоузлазним, дугосилазним и дугоузлазним акцентом, а прикази су употпуњени сликама. Оно што истраживање чини модерним и методолошки утемељеним јесте чињеница да су вредности фреквенције основног тона, изражене у херцима, претворене у полустепене (распон тонова). Аутор закључује да се према обрасцима тонског кретања не уочавају системске разлике ни код узлазних ни код силазних акцента, али да постоје индивидуалне реализације тонског кретања. 
У десетом (стр. 115-121) и тринаестом поглављу (стр. 148-152) обрађени су подаци о интензитету вокала у посматраним позицијама. Резултати спроведеног истраживања треба да одговоре на питање у којој су мери квалитетске дистинкције међу акцентима условљене специфичним интензитетским односима између вокала, да ли акценатске јединице утичу на вредности интензитета, као и сугласничко окружење. Аутор закључује да је акцентовани слог увек већег интензитета од ненаглашеног, да су више вредности забележене у дугим и наглашеним и ненаглашеним слоговима, као и то да су више вредности уочене код вокала у безвучном окружењу. Лончар Раичевић закључује да се највеће разлике између двеју група испитаника уочавају у погледу трајања акцентованих и неакцентованих слогова и остварења интензитета.

Од посебног значаја је четрнаесто поглавље - Неакиентоване дужине (стр. 152-171) у коме аутор износи детаљне податке о статусу неакцентованог квантитета у савременој говорној пракси. Прва два одељка у оквиру овог поглавља - Улога и општа правила остварена неакцентованог квантитета у српском језику (стр. 152-155), Неакцентовани квантитет у српској ортотонијској традицији (стр. 155-161), говоре о свим правилима о реализацији постакценатског квантитета, те су јасно и прецизно издвојене језичке категорије у којима се накцентована дужина јавља. Овај део може бити од значаја не само лингвистима и фонетичарима, већ свима онима који се баве јавним наступом. Аутор овде даје историјски преглед о улози неакцентованог квантитета и језичким стручњацима који су се бавили овом појавом - од Луке Милованова до данас. Након ових, следе наредна два поглавља у којима се аутор бави акустичком анализом неакцентованог квантитета, а од посебног значаја је закључак у коме Лончар Раичевић упућује на чињеницу да се у говору млађе популације јавља тенденција скраћивања дугих постакценатских вокала. Појединачни резултати показују да се неакцентована дужина најизразитије реализује иза краткоузлазног акцента.

У петнаестом поглављу књиге Дискусија и закљуиак (стр. 171181) аутор систематично резимира резултате експерименталног истраживања свих акустичких параметара. На основу укупних резултата свих испитиваних акустичких варијабли, аутор закључује да су уочене разлике на перцептивном плану потврђене и експерименталном анализом наведених јединица. Резултати анализе упућују на тумачење да обе групе испитаника у говору задржавају своју регионалну прозодијску основицу, а овакви подаци значајни су и за фонетска и за дијалектолошка истраживања.

Резултати укупне акустичке анализе прикупљеног материјала описују актуелно стање савременог српског говора и акустичку природу 
прозодијских јединица које су посматране у различитим узрасним групама говорника, што је предмет социофонетских истраживања. Овиме се отвара питање утицаја узраста на реализацију акустичких параметара у говору коме је аутор посветио пажњу у последњем поглављу - Социофонетски аспект проучаваға говора (стр. 181-193). Од посебног значаја су теоријски постулати представљени у одељку Хипотетички модели лингвистичких варијација - преглед титературе (стр. 184-192) у коме се даје преглед актуелне светске литературе и чиме се отварају питања за будућа истраживања оваквог усмерења у српском језику.

Имајући у виду све наведене чињенице можемо закључити да монографија Акустичка анализа прозодије речи у српском језику представља велики допринос науци о језику и проучавању говорног израза. У њој су употпуњена и обогаћена сазнања о акустичкој природи прозодије речи у српском језику. Кроз јасан стил и обиље података који су прецизно и табеларно систематизовани, уз мноштво пратећих илустрација, Александра Лончар Раичевић даје исцрпан опис акустичке природе прозодијских јединица у савременом српском језику, вршећи истраживања у продукцији говорника чији варијетет улази у ону дијалекатску базу на коју се непосредно ослања стандардни српски језик. На крају, још једном наглашавамо да је књига Акустичка анализа прозодије речи у српском језику вишеструко корисна, а ширина обрађених тема указује на њену свестраност: монографија ће бити корисна лингвистима, проучаваоцима фонетике и фонологије, прозодије, али и студентима језика, новинарима, лекторима, свима који имају интересовања за успешан језички наступ.

Нина Љ. Судимац

Универзитет у Нишу Филозофски факултет Департман за србистику nina.sudimac@filfak.ni.ac.rs 